\title{
On the Origins of the Japanese Language
}

\author{
Patrick Elmer
}

\begin{abstract}
In this article, I deal with the historical development of the Japanese language by applying a multidisciplinary approach that uses data from a variety of fields. My research indicates that the homeland of the Japonic language family may have been in the lower Yangtze River Valley, from where its speakers moved to the Korean Peninsula and eventually to Japan during the Yayoi period. This spread is associated with the dispersal of wet rice agriculture from the area south of the Yangtze River via the northeastern Asian mainland, where it was in contact with cultures cultivating millet. Old Japanese mythology and genealogical data suggests that the earliest known ethnic group that spoke Japonic may have been the Hayato people of southern Kyūshī. ${ }^{l}$
\end{abstract}

Keywords: Language origins, Japonic, Hayato, Wa, farming/language dispersal hypothesis

\section{S sciendo}

Elmer, Patrick. 2019. "On the Origins of the Japanese Language" Vienna Journal of East Asian Studies, 11, pp. 212-239.

https://doi.org/10.2478/vjeas-2019-0008

\footnotetext{
${ }^{1}$ This article is based on my M.A. thesis (Elmer 2019).
} 


\section{Introduction}

Japanese is part of the Japonic language family, consisting of Japanese, the Ryūkyū 琉球 languages (Amami 奄美, Okinawa 沖縄, Miyako 宮古, Yaeyama 八重山, Yonaguni 与那国), and possibly Hachijo 八丈. ${ }^{2}$ This article deals with the origins of the Japonic language family ${ }^{3}$ and the spread of Japonic to the Japanese archipelago. In this article, I use "Japonic" to refer to historical stages of the languages that are directly related to modern Japanese. The term "Japonic languages" also includes Ryūkyūan and language fragments from the Korean Peninsula ${ }^{4}$ that are thought to belong to the same language family as Japanese.

In the past, scholars have compiled extensive word lists to compare the Japanese language with languages of the Korean Peninsula as well as with language families from the south, like Austronesian and Tai-Kadai (Martin 1966; Kawamoto 1977; Whitman 1985; Benedict 1990; Starostin Dybo and Mudrak 2003; Robbeets 2005). Other attempts have connected Japanese to other geographical regions through myth, belief, and religion. This has led to a multitude of competing theories on the origins of the Japanese language. I believe that only a theory that incorporates all available data from different disciplines is suitable for successfully dealing with such a complex question. I will therefore consider data from several areas, such as genealogy, archaeology, mythology, cultural anthropology, and historical written sources. This will provide a basic understanding of different data from various fields, which should then be reconciled to generate a more coherent picture of the prehistory and origins of the Japanese languages. More specifically, I try to answer the question of the earliest traceable geographical origin of the ethnic group that spoke Japonic and what route these people took to the Japanese archipelago.

\section{Previous Research}

The origins of the Japanese language have been debated among generations of scholars, but despite extensive research, no satisfying answer has yet been found (see sections Southern connections and Northern connections). In this section, I will give an overview and examine the main theories developed and discussed in the last decades. It is believed that the Japanese islands have experienced two major immigration waves, the first of which occurred during the Jomon 縄文 period (ca. 15,000-300 BCE), followed by a second major immigration wave during the Yayoi 弥生 period (ca. 300

\footnotetext{
2 This is still debated, and more research is needed to verify the position of Hachijo (Pellard 2015: 16).

${ }^{3}$ A language family consisting of Japanese and Ryūkyūan.

${ }^{4}$ Some authors follow Juha Janhunen's naming convention and label the "historical varieties of the Japanese language spoken on the Korean Peninsula" as "Japanic" (Robbeets 2017: 211, note 1).
} 
$\left.\mathrm{BCE}^{5}-300 \mathrm{CE}\right)$. This is known as the "dual structure hypothesis" which was formulated by Hanihara Kazurō 埴原和郎 (Hanihara 1991). The Jōmon people were a hunter-gatherer society that occupied the Japanese islands until extensive immigration occurred from the Korean Peninsula, giving rise to the ensuing Yayoi culture that introduced wet rice agriculture, iron tools, and other technologies during the first millennium BCE (Takahashi 2009; Iizuka and Nakahashi 2012; Miyamori et al. 2015).

Most scholars consider the emergence of the Japanese language on the Japanese archipelago to coincide with this Yayoi immigration. However, it is unclear whether the Yayoi immigrants replaced the language spoken on the islands with their own language from the Korean Peninsula. Some researchers also assume that the language of the Jomon people and the language of the Yayoi immigrants intermixed and created a new, mixed language. In the following, I will provide different scholarly opinions on the origins of the Japanese language that relate Japanese to geographical areas north and south of Japan.

\section{Southern Connections}

The most prominent theory that assumes the original area of Japonic is to the south of the Japanese archipelago is the Austronesian hypothesis. A possible language relationship between Japanese and Austronesian was first mentioned by Shinmura Izuru 新村出 in 1911 and Soviet linguist E. D. Polivanov in 1924 (cited in Hudson 1999: 267). The theory of a relationship with the Austronesian languages received attention after the publication of Japanese linguist Ōno Susumu 大野晋 in 1957. According to Ōno, an Austronesian language was present in the Japanese archipelago before the language of the Yayoi immigrants came to the Japanese islands. The Austronesian language remained as a substratum in the newly formed language (Ōno 1970: 70). Following Ōno's publication, Kawamoto Takao 川本崇雄 (1977) developed an extensive word list consisting of a total of 721 possible Japanese and Austronesian cognate pairs. In 1990, Paul K. Benedict published a monograph relating Japanese to the Austro-Tai language branch, but did not fully agree with Kawamoto, stating that Kawamoto records "“look-alikes' rather than cognate sets" (Benedict 1990: 2). He instead proposed an "Austro-Japanese" language family consisting of Austronesian and Japanese-Ryūkyūan as part of his Austro-Tai macro family. Robert Blust, a historical linguist specialising in Austronesian languages, opposed a connection between Austronesian and Japanese and pointed out that "virtually every etymology is problematic in one or more ways" in Kawamoto's work (Blust 2013: 704).

\footnotetext{
5 The traditional dating to about 300 BCE was challenged in 2003 when Accelerator Mass Spectrometry (AMS) was used to analyse charred remains that stuck to pottery samples. The results meant that the beginning of the Yayoi period needs to be dated to a time about 500 years earlier than previously thought (Shōda 2007: 1). See section Rice in Japan for more information.
} 
Based on archaeological research, a connection between the Austronesian speakers and the Japanese islands seems to be confined solely to the southernmost Ryūkyū Islands of Yaeyama, Yonaguni and Miyako. Summerhayes and Anderson (2009) as well as Mark Hudson (2012) have shown that the gap of roughly 300 kilometres between these southern Ryūkyū Islands and Okinawa was probably never bridged in prehistorical times; cultural Austronesian influence is restricted to the Sakishima islands in the very south of the Ryūkyū Island chain. Hudson claims that "[t]he Sakishima islands of the southern Ryukyus were settled around 4300 years ago by a quite different group of people(s) who seem to have come not from Japan, but from somewhere in Taiwan and/or Southeast Asia." He proceeds that "the archaeological record offers no evidence for the movement of people or artefacts across the gap between Okinawa and Miyako Islands, and it is widely assumed that this marks the boundary between two different cultural zones" (Hudson 2012: 258-259).

\section{Northern Connections}

In 1966, Samuel Martin proposed a genetic relationship between Japanese and Korean based on extensive lexical comparisons of the two languages. In his study, Martin created a list of 320 etymological entries which he related to Korean, Middle Korean, Japanese, Old Japanese, Altaic languages (Turkic, Mongolic, Tungusic), and others. His seminal work advanced the comparison of Japanese with languages from the Korean Peninsula greatly and gave rise to the Altaic theory, where Japanese and Korean are incorporated in the Altaic language family. Based on this research and works by G. J. Ramstedt and Nikolaus Poppe, Roy Andrew Miller (1971) further developed the Altaic theory in 1971. Following this, Japanese linguist Murayama Shichirō 村山七 郎 published a monograph on the connections between Japanese and the Altaic language family together with Ōbayashi Taryō 大林太良. Murayama proposed a Malayo-Polynesian substratum in the Japanese language in addition the Altaic elements (Murayama and Ōbayashi 1973).

Another monumental publication arguing for an Altaic-Japanese connection is that of Russian historical linguist Sergei Starostin (1991). In subsequent years, the connection of Japanese with the Altaic languages was advanced with the publication of the 2003 Etymological Dictionary of the Altaic Languages (Starostin, Dybo, and Mudrak 2003). Martine Robbeets analysed a set of 2055 lexical items and found 359 lexical etymologies that show a "regular phonological fit for the initial consonant, the medial vowel and the medial consonant of the Japanese entry," which led her to believe that the relationship between Japanese and the Altaic languages is genetic (Robbeets 2005: 422).

Early scepticism of the Altaic hypothesis goes back to Gerhard Doerfer (1974), J. Marshall Unger (1990), Juha Janhunen (1992; 1994), and Georg et al. (1999), among others. Although himself an early proponent of the Altaic hypothesis (Vovin 1999), 
Russian linguist Alexander Vovin was among the most vehement critics of the theory after the turn of the century and heavily criticised the Etymological Dictionary of the Altaic Languages (Vovin 2009: 141).

Some scholars have focused solely on the relationship between Korean and Japanese as incorporating the Japanese language into the larger Altaic language group has proven difficult in research. According to Marshall J. Unger, a proto-Korean-Japanese language developed on the Korean Peninsula and migrated to the Japanese islands around the third century BCE, splitting into what would later become Korean and Japanese (Unger 2001: 247). While Unger's research was generally well received by linguist John Whitman (2010), Vovin's monograph (2010) published almost at the same time holds a very different opinion. According to him, the similarities of Korean and Japanese cannot be explained by a genetic relationship of the two languages, but rather by intense contact that led to heavy borrowing (Vovin 2010: 3). Despite close lexical similarities, Vovin points out some fundamental typological differences, for example that historically Korean is an ergative language while Japanese is nominative. Additionally, the Korean passive seems to be quite young, having developed from a causative construction, as well as an ablaut, which is still active in Korean colour terms and onomatopoetic words. He concludes that this "suggests $[. .$.$] convergence,$ not divergence" (Vovin 2010: 6-7).

\section{Reconciling Northern and Southern Theories}

Many attempts have also tried to reconcile the two major theories outlined above. David Solnit compared the proposed cognate sets of the Altaic as well as the Austronesian hypothesis and concluded that his results seem "to mirror the notion of coexisting Austronesian and Altaic strata in the Japanese lexicon" (Solnit 1992: 194). Recent publications from Japanese scholars include Japanese linguist Itabashi Yoshizō 板橋義三, who assumes that Old Japanese had some basic vocabulary and parts of the grammar from Austronesian, while the rest is of Altaic origin (Itabashi 1999: 54-55; 2003). In 2015, Itabashi postulated that the Jōmon language came to Japan from the south, then spread to the north and finally turned into a mixed language with elements from Austronesian, Hmong-Mien languages, Chinese, Korean and the language of Koguryŏ 高句麗 (Itabashi 2015: 52). A similar idea is advocated by Sakiyama Osamu 崎山理, who inferred that rice came to Japan before the Yayoi period by examining the distribution of rice and the words for it in the Japanese islands (Sakiyama 2012: 390). According to his theory, rice agriculture was brought to Japan by a group that originated in the southern Chinese mainland (Sakiyama 2012: 356).

Most researchers today acknowledge that the Japanese language has been influenced from the Korean Peninsula as well as from the southern part of mainland China. However, there is no agreement on whether language similarities are typological or genetic. This means that it is not clear which element (Altaic or Austronesian) is the 
superstratum. Careful examination of the known Japonic languages might help in answering those questions in future research.

\section{Japonic Fragments in Korea}

Another important theory was put forward in 2004 by Christopher I. Beckwith who proposes a relationship between Japanese and the language of the historical Koguryŏ kingdom (trad. 37 BCE-668 CE) in the north of the Korean Peninsula. His research is based on toponyms recorded in Samguk sagi 三國史記, the first Korean historical source from the twelfth century CE. Many lexemes reconstructed from these toponyms have been connected to Japonic. Therefore, this corpus constitutes an important historical source on the Japonic language family.

The toponyms from the geographical sections of the Samguk sagi (volumes 35 and 37) correspond with three provinces of the southern Koguryŏ territory that were conquered by Silla 新羅 in central Korea (Beckwith 2004: 50). ${ }^{6}$ Those place names were often directly translated into the Silla language and thus it is possible to reconstruct lexical items of its underlying language. Christopher Beckwith has analysed these lexical items and concluded that they represent a language similar to Japonic. He was able to record "[a]bout 130 clearly identifiable words and function morphemes from the area of the former Koguryo kingdom" from the eighth century CE, in addition to fourteen lexemes from the third century CE (Beckwith 2004: 236-237).

These toponyms have been interpreted by Beckwith as the language of the Koguryŏ kingdom. However, connecting these place names with the language of the Koguryŏ kingdom is not the only possibility. Opponents of Beckwith's theory claim that these toponyms may have already existed before Koguryŏ conquered the area and therefore this may only show a substratum language and not the native language of the Koguryŏ kingdom (Beckwith 2004: 236). Thomas Pellard criticises Beckwith's reconstructions and conclusions on the grounds of methodological shortcomings, but nevertheless states that "some of the Koguryo place names indeed represent in all likelihood a language related to Japanese that was once spoken in the center of the Korean peninsula" (Pellard 2005: 168-169).

Finnish linguist Juha Janhunen considers Koguryŏ to be a Tungusic language. According to him, Japonic may have also been spoken in southern Koguryŏ, but he maintains that "the principal territory of the toponymic corpus is located in central Korea, in an area that was only secondarily transferred from Paekche to Koguryŏ" (Janhunen 2005: 76). The language of the toponyms may therefore be considered to have been that of the Paekche 百濟 kingdom. He concludes that it "has now been unrefutably

\footnotetext{
${ }^{6}$ According to Vovin, these "Japonic-looking" place names were mainly from the Han River basin near present-day Seoul (Vovin 2013: 236); Whitman thinks that they extend "as far as modern North Hwanghae province, south of the later Koguryŏ capital at P'yŏngyang”' (Whitman 2011: 154).
} 
(sic) confirmed that the language of these toponyms represents a form of speech closely but collaterally related to the Japonic languages (Japanese-Ryukyu), as spoken on the Japanese Islands" (Janhunen 2005: 70).

Alexander Vovin considers Japonic to represent a substratum that was present on the Korean Peninsula and can be detected in the languages of Paekche and Silla, but not in Koguryŏ (Vovin 2013: 222). He adds further data from the Liáng shü 梁書 and Samguk sagi (vol. 34) and concludes that the "Silla territory had originally Japonic substratum language(s) that was/were eventually assimilated by Korean" (Vovin 2013: 236). With that, he suggests a "gradual replacement of Japonic languages by languages closely related to Korean" from the Han River basin to the south of the Korean Peninsula (Vovin 2013: 236).

The data presented so far suggests that Japonic and Koreanic were present in the south of the Korean Peninsula. Different theories consider the language of Koguryŏ to be Japonic (Beckwith 2004), Tungusic (Janhunen 2005: 84), or a variety of Old Korean (Unger 2009: 81-82; Nam 2012: 51; Vovin 2013: 224). ${ }^{7}$

One problem with interpreting the toponym data is that the influx of Yayoi immigrants to the Japanese archipelago started significantly earlier than the Three Kingdoms period. The language data presented above may be over 1,000 years younger than the language of the first speakers of Japonic on the Japanese island of Kyūshū 九 州. Concerning the relationship between the Koreanic and Japonic languages families, one important question to answer is whether Japonic and Koreanic are genetically related and can therefore be put in the same language family. It remains to be seen if researchers can agree on an interpretation of those toponyms and its relevance for the origins of Japanese.

\section{Methodology}

Linguistic data on the early historical stages of Japanese alone is not sufficient for analysing the development of the Japonic language family. This multidisciplinary approach therefore utilises a variety of data to enhance the picture of how the Japanese language evolved through the course of time and where it could possibly have come from. Additionally, I aim to provide cultural reconstructions of the people who can be assumed to have spoken a Japonic language. Principally, I follow the historical method outlined by Richard Zgusta (2015: 9-20). It is based on sources from the following fields for the historical reconstruction of non-literate cultures: (1) ethnology, (2) archaeology, (3) historical and comparative linguistics, (4) oral and documentary

\footnotetext{
${ }^{7}$ However, Beckwith states that in the Koreanic-speaking Silla kingdom area in the southeastern part of the Korean Peninsula, the toponyms from the Samguk sagi can only be related to Korean but not to Japanese (Beckwith 2010: 216).
} 
history, and (5) biological anthropology (Zgusta 2015: 9). These general fields provide the information that will then be analysed with the methods given below.

One of the most important principles of the multidisciplinary approach is that of "cross-disciplinary verifications" (Zgusta 2015: 12). Archaeologist Peter Bellwood also points out that a coherent reconstruction of the genesis of language families can only be achieved by connecting language spreads to language speakers and subsequently to archaeological records (Bellwood 2005: 19). Failure to do so will result in erroneous interpretations based on skewed data samples. Therefore, it is necessary to evaluate the available data carefully to construct a balanced view that incorporates diverse sources without favouring one discipline over the others (Zgusta 2015: 13).

Connecting genetic language families to culture areas in combination with archaeological data is useful for reconstructing the migration of ethnic groups and their homelands. However, culture areas and language families overlap only in some cases, such as in Polynesia or the Bantu language and the Congo rainforest (Zgusta 2015: 11). In the case of Japanese, this concept may be applicable as long as the Japanese culture and language were present in the geographically confined area of the Japanese archipelago. This is complicated by the contact situation between Japonic and Koreanic speakers and may thus only be appropriate in specific cases in the history of Japonic. Owing to the complex nature of the cultural interactions on the continent, this concept cannot be used to reconstruct migratory movements outside of Japan in the more distant past.

The Wörter und Sachen technique connects people to cultures and language families. It assumes that if words referring to something can be reconstructed for a protolanguage, the thing that it indexes was likely of cultural importance (Crowley and Bowern 2010: 312). This method mainly focuses on the comparison of lexical cognates, which "leads to a historical study of divergence from an ancestral protolanguage to daughter languages that make up a language family" (Zgusta 2015: 14). Focusing on borrowings also offers valuable information on the route of cultural and lexical dispersal and studies the "convergence of languages spoken within a defined area" (ibid).

Additionally, written historical sources as well as oral histories provide an important source of information. When interpreting those sources, it is necessary to understand the context of how the information was recorded, because in many cases historical texts show an external perspective and were written in a different cultural background. As a result, the texts depict an incomplete picture that often emphasises exotic elements and is distorted by the worldview of the writers (Zgusta 2015: 16). The effectiveness of this multidisciplinary approach relies heavily on the availability of data, which is often insufficient for reconstructing the prehistory of a language. It is therefore inevitable that some aspects of a language cannot be recovered through cross-checking of different disciplines and some holes in the cultural reconstruction need to be tolerated (Zgusta 2015: 17). 


\section{The Earliest Known Speakers of Japonic: The Wa People}

In this section, I will locate the earliest recorded speakers of Japonic who can be traced in historical sources by connecting them to an ethnic group. The first Japanese sources are only available from the eighth century CE, but earlier Chinese sources provide valuable information on the inhabitants of the Japanese islands before that time. These sources refer to the Japanese as Wa people (Chinese: wōrén 倭人). In the following, I will outline the earliest evidence of the Wa language by using old Chinese sources.

The first information on what language the Wa people spoke can be found in the third century History of the Three Kingdoms (Sānguó zhì 三國志) compiled by Chén Shòu 陳壽 (233-297 CE). In a section known in Japanese as Gishi-Wajinden 魏志倭 人伝, it records sixteen titles, twenty-nine place names, and six personal names of the Wa language. A few place names can be linked to contemporary places in northern Kyūshū: Tsushima (in the original Chinese source written as 對馬 *tuəs-ma ${ }^{\mathrm{B} 8}$ ), Iki (一支 $9 *$ Pit-kie), Matsura (末盧*mat-la), and Ito(shima) (伊都*?i-to). Although linguistic material is sparse, this suggests that the language of the Wa people is related to Japanese. Additional data can be gathered from the titles of officials that were recorded. Some can be connected to Old Japanese titles such as piko ("prince," 卑狗 *pie-ko ${ }^{\mathrm{B}}$ ) or mori ("guard,”母離 *mə⿳亠丷厂 ${ }^{\mathrm{B}}$-liai).

Marc Miyake (2003) treats this language data as Pre-Old Japanese and hence part of the Japonic language family. Similarly, extensive research on the language data from the Gishi-Wajinden carried out by Bentley (2008) also leads to the conclusion that the Wa people spoke Japonic. Therefore, it is safe to assume that the Wa people spoke Japonic in the late Yayoi period.

Possibly the oldest source that mentions the area of the Wa people is the Chinese text Guideways through Mountains and Seas (Shānhăijīng 山海經). It covers various old Chinese beliefs such as religion and mythology and also gives insights into the geography, flora, and fauna of the Chinese cultural sphere. There is no exact date of when it was written, but it is usually considered to have been compiled between the fourth and the first century BCE (Strassberg 2002: xiii). This is the short section that vaguely records the location of Wa:

蓋國在鉅燕南, 倭北。倭屬燕。朝鮮在列陽東, 海北山南。列陽屬燕。(Shānhăijīng vol. 12). Gài chiefdom is south of Great-Yàn and north of Wa. Wa is subject to Yàn. ${ }^{10}$ Chosŏn is east of Liè Yáng and south of the Hăiběi mountains. Liè Yáng is subject to Yàn.

\footnotetext{
${ }^{8}$ Reconstructed transcriptions are based on Later Hàn 漢 Chinese (Schuessler 2009). Superscript B indicates 'rising' tone (Schuessler 2009: 6).

${ }^{9}$ Written as 一大 in the original, but probably a misspelling for 一支, as it is clear from the records that it refers to Iki-no-shima 壱岐島.

${ }^{10}$ An ancient Chinese state during the Zhōu 周 dynasty (ca. 1046-256 BCE).
} 
The Yàn 燕 state fell in 222 BCE and Chosŏn 朝鮮11 (which existed until 108 BCE) became the "most powerful political authority to the east of Liaohe" in the fourth and third century; it was the "only power that could confront the [Yàn] dynasty in those days" (Song 2004: 99). Accordingly, the entry seems to refer to a time before 222 BCE and possibly after the fourth century BCE. The Gài chiefdom 蓋國 can be connected to the Kaema 蓋馬 Plateau in present-day North Korea (Cheng, Cheng, and Thern 1985: 199, note 32). This suggests that the location of Wa was in the central or southern part of the Korean Peninsula or on the Japanese archipelago.

The Shänhäijīng contains "a wide range of beliefs held by the ancient Chinese about their world" and has been "repeatedly hand-copied, reprinted, and re-edited through the centuries into our own time" (Strassberg 2002: xiii). Therefore, this historical text is not reliable enough to allow any definite statements about the early history of the Wa. The most valuable information from the entry in the Shänhăijing is that the Chinese character for "Wa" existed during the time of Chosŏn and denoted a polity recognised by the Chinese. Additional information needs to be considered to fully understand this text fragment.

Other information can be found in the Lùnhéng 論衡, which was written in the first century $\mathrm{CE}$ and includes mentions of the Wa people dating even further back in time. A short entry places the Wa during the time of the Zhōu dynasty, but does not provide any further details on their location:

\section{周時天下太平, 越裳獻白雉, 倭人貢䀝草。(Lùnhéng vol. 26).}

During the [Zhōu] time there was universal peace. The [Yuè] offered white pheasants to the court, the [Wa] odoriferous plants (Forke 1907: 505).

A second entry from the Lùnhéng is more specific concerning the timing and indicates that both entries refer to a time at the beginning of the Zhōu period:

成王之時, 越常獻雉, 倭人貢暢。(Lùnhéng vol. 58).

In the time of [King Chéng 成 of Zhōu (1042-1021 BCE)], the [Yuè] presented a pheasant, and the [Wa] brought odoriferous plants as tribute (Forke 1962: 208).

It is noticeable that the Wa people are mentioned alongside the Yuè 越 in both instances. This may be taken as an indication that the Wa were living close to the Yuè of southeast China during that time. However, given the Lùnhéng describes events that took place 1,000 years before the book was written, the accuracy of the historical source may be questioned.

\footnotetext{
${ }^{11}$ Contemporary sources refer to it as Kojosŏn 古朝鮮, but I will use Chosŏn to reflect the original Chinese characters (朝鮮). The characters 古朝鮮 were only used much later.
} 


\section{Mythological Homeland of the Wa People}

Additional evidence that points to the Wa's origins in southeastern China can be derived from an old association of the Wa with the mythical figure of Wú Tàibó 吳太 伯 (hereafter Tàibó). Some Chinese sources record that the Wa people consider themselves to be descendants of Tàibó. The first such mention is a brief entry in volume 54 of the Liáng shu (written from 626-636 CE), followed by a more substantial entry in volume 97 of the Jinsh $\overline{\text { 晉書 }}{ }^{12}$ (written from 626-649 CE).

Given these entries, understanding the mythological stories about Tàibó could provide important information for assessing the homeland of the Wa people. According to the Shĭji 史記 (ca. 94 BCE), Tàibó was the eldest of three sons of King Tài 太 of Zhōu. His second son was Zhòngyōng 仲雍 and the youngest was named Jìlì 季歷. Because Jilì was the preferred heir of the king, Tàibó and Zhòngyōng moved southeast to step aside (Nienhauser 2006: 1-3). Based on a variety of historical Chinese sources such as Wúyuè chūnqiū 吴越春秋 (The Annals of State Wú and State Yuè) (Trairong and Wu 2016: 196), ${ }^{13} \mathrm{Wu}$ Ben-li summarises that Tàibó and Zhòngyōng moved to an area in the lower valley of the Yangtze (Chángjiāng 長江) River (present-day Níngzhèn 宁镇 area, Jiāngsū 江蘇 Province) — the area of the indigenous Jīng Mán 荊蠻 people (Trairong and Wu 2016: 44). The Jing Mán tribe were local people in the lower Yangtze area with customs quite unlike that of the Zhōu.

These "Jing Man" natives cut their hair short and tattooed their skins. They spoke like birds singing, not a single word could be understood. Furthermore, their local customs and habits were very difficult for the Zhou people to accept. In the same river men and women had their bath naked together. It ran counter to all established customs of the House of Zhou. [...] The local natives lived by the products of the river. All of them could swim in the river and lived on catching fishes, eating raw fishes. They believed that the dragon tattooed on their skin could prevent them from any harm from fierce fish such as crocodiles (Trairong and $\mathrm{Wu} 2016$ : 46).

In the Lùnhéng, the native Jīng Mán are called Wú 吳 (as they lived in the area of the later Wú state 吳國). Tàibó is said to have gone to their area “where he collected medicinal herbs, ${ }^{14}$ cut off his hair, and tattooed his body, to follow the customs of $W u$ " (Forke 1962: 380)..$^{15}$ Tàibó was regarded as an able ruler and the Jīng Mán followed him (Nienhauser 2006: 1-3). With this, Tàibó was successful in establishing the state

\footnotetext{
12 An official Chinese historical text on the history of the Jìn 晉 dynasty (265-418 CE) compiled during the reign of Emperor Tàizōng 太宗 of Táng 唐 (r. 626-649 CE) (Hong 1994: 284).

${ }^{13}$ Unfortunately, Wu only provides a list of the sources he used, but does not cite the specific text passages.

14 Tàibó is quoted several times as looking for medical herbs in the Lùnhéng (see Forke 1907: 300; Forke 1962: 209).

15 Another entry shows a contrary picture: " $T$ 'ai Po taught the $W u$ to wear a cap and a girdle, how would he have followed their customs, and been naked, as they were? Thus the $W u$ learnt propriety and righteousness, and it was T'ai Po who changed their customs" (Forke 1907: 124).
} 
of Wú in the lands south of the Yangtze River (Trairong and Wu 2016: 48). The description of the Jīng Mán bears some striking resemblance to that of the Wa people in Chinese records. Below is the relevant description of the Wa people in the Sänguó zhi:

夏後少康之子封於會稽, 斷髮文身以避蛟龍之害。今倭水人好沈沒捕魚蛤, 文身亦以厭 大魚水禽, 後稍以爲飾。(Sānguó zhì vol. 30).

A son of the ruler Shao-kang of Xia as ruler of Kuai-ji cut his hair and decorated his body with patterns to avoid harm from dragons. Now, the Wa water people, who are fond of diving to catch fish and for clams, also decorate their bodies in patterns to prevent being annoyed by large fish and water fowl (Kidder 2007: 14).

Both people are said to have tattooed their bodies to avoid harm from water creatures. It may be asked how close the Jing Mán and the Wa people were in terms of culture and language. If the mention of Tàibó as ancestor of the Wa people in Chinese sources can be used as indication of cultural connections, there is a possibility that the $\mathrm{Wa}$ people originated in an area in southeast China. ${ }^{16}$ In turn, this could also possibly be the homeland for Japonic. To further review this possibility, I will now turn to methods better suited for connecting language origins to a geographical area.

\section{Rice Spread from the Lower Yangtze River}

The "farming/language dispersal hypothesis" (Bellwood and Renfrew 2002; Bellwood 2005) is an important concept that sheds light on the historical affiliations of a language family with its geographical expansion over time. This can be achieved by connecting the farming-related vocabulary of protolanguages to the archaeology of these early farming technologies and thus ties a language family to a geographical area during a certain period of time. Archaeobotanical evidence can explain where the cultivation of certain crops began, how its domestication progressed, and how the agricultural subsistence system led to its carrier's expansion (Stevens and Fuller 2017: 175).

This hypothesis is based on the assumption that better farming technologies will facilitate population growth and subsequently lead to greater population densities. This in turn leads to the expansion of early farming societies, settling new lands and spreading their agriculture and languages in doing so (Stevens and Fuller 2017: 154). It should also be noted that there are examples of languages originating among hunter-

\footnotetext{
${ }^{16}$ According to Sarah Allan, the Xià 夏 dynasty (trad. ca. 2200-1760 BCE) was consistently associated with dragons and water creatures (Allan 1984: 242; 252). Kuàijī can be connected to the Kuàijī mountains 會稽山 in the lower Yangtze River Delta. The stories of Tàibó and the son of Shăo Kāng may have been conflated in later entries.
} 
gatherer societies (for example Uralic, Eskimo-Aleut, Athabaskan, and Algonquian in Canada) as well as agriculturalist language families (for example Egyptian, Sumerian, Mixe-Zoque, and the Caucasian language families) that did not spread (Bellwood 2005: 19).

In the following sections, I will consider the bioarchaeology of Japan and the Japanese vocabulary related to early agriculture in Japan. Three main theories concerning the introduction of wet rice agriculture in Japan are considered among researchers. Wet rice agriculture came either from the northern parts of Korea, from central coastal China, or from southern China through the Ryūkyū Islands (Takamiya 2001: 210). The route through the Ryūkyū Islands is unlikely "since no archaeological data indicate that the late Middle to Late Jomon culture elements have any link to the south" (Takamiya 2001: 222). Satō Yōichirō 佐藤洋一郎 suggests a "south-north dual origin hypothesis:" first, upland rice came from the south and subsequently paddy field rice cultivation came from China via the Korean Peninsula (Satō 1992: 732). Most scholars agree that Japanese rice was introduced from China via the Korean Peninsula. The southern origin of Japanese rice is advocated by Yasuda Yoshinori 安田喜憲 who places the origin of Japanese rice around the lower reaches of the Yangtze River in south-eastern China (Yasuda 2009: 58). Since Japanese rice seems to have come from an area in south-eastern China, the development of rice agriculture provides useful information for assessing the spread of the language related to it.

\section{The History of Rice Cultivation}

I will now give a brief overview of the historical development of rice cultivation in China. There were two main independent cultural centres where the transition from foraging to farming took place: the middle Yangtze Valley based on rice (Oryza sativa), and the middle Yellow Valley based on foxtail millet (Setaria italica) (Lu 1998: 277-278; Bellwood 2005: 20). In prehistoric South China, the indigenous foraging culture and the farming culture from the Yangtze River Valley seem to have interacted and co-existed over an extended period of time (Lu 2012: 131). From the beginning of agriculture in China around $8000 \mathrm{BCE}$, there was a basic separation based on millet agriculture in the lower basin of the Yellow River to the north, and on rice agriculture in the lower basin of the Yangtze to the south.

Full domestication of rice was reached in the Lower Yangtze around 4000 BCE and there is no evidence of millet or soybeans in Lower Yangtze agriculture until ca. 2000 BCE. Millet and rice developed separately in different regions until millet farmers eventually took up rice agriculture and created an integrated system for millet and rice (Stevens and Fuller 2017: 166-168). Millet and rice also individually reached the Korean Peninsula. First, millet came around 3500-3000 BCE across the sea from the Chinese mainland or via Liáoníng 辽宁 into Northern Korea. Then, rice arrived around $1500 \mathrm{BCE}$, possibly through the same route. Eventually, millet and rice spread 
to Japan around 700-600 BCE, but the evidential basis for dating is relatively poor with wide error margins (Stevens and Fuller 2017: 170-171). As for the spread to Japan, Nasu and Momohara assume that "rice and millet cultivation were simultaneously introduced as a set, part of the agricultural complex into the existing Jomon subsistence economy" from China via Korea during the initial Yayoi period (Nasu and Momohara 2016: 504; 510).

Accurately dating the introduction of rice and millet agriculture in Korea and Japan is difficult, because the available data is not sufficient. Finds of foxtail millet, barley, rice, wheat, hemp, and legumes at an excavation site in North Ch'ungch'ŏng 충청 북 Province are problematic "[b]ecause of an incorrect identification and a lack of direct accelerator mass spectrometry (AMS) dates on these crop remains" (Lee 2003, cited in Lee 2011:313). These finds may therefore be more recent than previously thought (Lee 2011: 313). Other sites in Korea also have dating problems and the earliest reliable evidence points to a date in the late second millennium BCE (Stevens and Fuller 2017: 171). Archaeological evidence suggests that rice spread from the lower Yangtze region via the Korean Peninsula to Japan, but because of a lack of data it is not possible to locate and date the emergence of the integrated millet and rice subsistence system that reached Japan in the Yayoi period.

\section{Rice in Japan}

The earliest archaeological finds of rice in the Japanese archipelago are thought to be dry-field rice and did not have any significant sociocultural impact on the Jomon populations. It was not until the introduction of irrigation technology from the Korean Peninsula at the start of the Yayoi period that profound changes in lifestyle set in (Takamiya 2001: 209; Nasu and Momohara 2016: 505). The existence of paddy fields and wet rice agriculture is one of the best indicators for determining the start of the Yayoi period. Excavations at the Itazuke 板付 site (Fukuoka 福岡) have revealed paddy fields, irrigation channels, water reservation ponds, and carbonised rice which suggest that rice cultivation was already present in northern Kyūshū around 935-915 BCE (Rhee et al. 2007: 415-416; Takahashi 2009: 71).

Shitara Hiromi 設楽博己 argues that the Yayoi culture was a complex of multiple farming cultures which was gradually formed as a result of acceptance of various agricultural methods that developed in areas based on the respective environments (Shitara 2014: 465). A temporal framework is given by Fujio Shin'ichirō 藤尾慎一 郎 who believes that rice cultivation during the Yayoi period started in the tenth century BCE in the coastal regions of the Genkai Sea (Genkai-nada 玄界灘). At the end of the eighth century BCE, it reached the northern coast or the Ariake Sea (Ariake-kai 有明海) and left the island of Kyūshū in the seventh century BCE. After this, it quickly spread westward to the Kansai 関西 area (Fujio 2014: 140). 
John Whitman claims that the introduction of wet rice coincides with the arrival of the Japonic language family in the Japanese archipelago, which came with the Yayoi settlers in around 950 BCE, reaching Japan's inland sea in around 600 BCE. $\mathrm{He}$ states that the introduction of the Koreanic language family and the resulting disappearance of the Japonic languages from the Korean Peninsula occurred around 300 BCE (Whitman 2011: 149). Miyamoto Kazuo 宮本一夫 also advocates what he labels the "demic diffusion theory" (Miyamoto 2016: 54) which postulates four stages for the development of agriculture in Northeast Asia: (1) spread of millet agriculture to the Korean Peninsula (ca. 3300 BCE); (2) spread of wet rice agriculture from the Shāndōng 山東 Peninsula to the Liáodōng 遼東 Peninsula (ca. 2400 BCE); (3) spread of polished stone tool agriculture (ca. $1500 \mathrm{BCE}$ ); and (4), spread of irrigated agriculture from the southern Korean Peninsula to northern Kyūshū (ca. eighth century BCE) (Miyamoto 2016: 53-56). Both Whitman and Miyamoto connect the presence of Japonic on the Korean Peninsula with the Mumun 無文 culture which arrived there around 1500 BCE (Whitman 2011: 157, Miyamoto 2016: 70-72).

The origins of rice agriculture in combination with millet cultivation plays an important role for tracing the immigration movements during the Yayoi period. It remains to be seen where the contact of these two elements and associated vocabulary in the Japonic language has occurred, but archaeological data on rice and millet suggest that this happened outside of Japan before the start of the Yayoi period.

\section{Cultural Vocabulary}

If we accept the hypothesis that rice came to Japan from the coastal areas of southeastern China, the vocabulary for terms related to rice agriculture used in Japanese should also reflect this. Sakiyama Osamu analysed rice-related terms in Japanese and concluded that they can be connected to the Austronesian language family that originated in Taiwan. Through his research, he listed ten rice-related terms that have Austronesian cognates (Sakiyama 2012: 390). This fits well with Whitman's view that Proto-Koreanic and Proto-Japonic do not share any vocabulary related to wet rice cultivation (Whitman 2011: 156). This also entails that if Proto-Koreanic and Proto-Japonic were related, they must have split before Proto-Japonic attained vocabulary for wet rice agriculture (Whitman and Hudson 2017: 149). It is more likely that the lack of shared rice vocabulary between Koreanic and Japonic indicates that the two language families are not genetically related ${ }^{17}$ and that rice agriculture developed individually in Korea and Japan.

\footnotetext{
${ }^{17}$ Martine Robbeets does not rely on the "farming/language dispersal hypothesis" and explains the Japanese vocabulary for wet rice cultivation as loans from Proto-Austronesian. According to her, coastal subsistence terms are shared between Japanese and Korean (Robbeets 2017: 222).
} 
According to the "farming/language dispersal hypothesis," the southern origin of the Japanese rice plant and rice-related vocabulary of Japanese point to the lower Yangtze area as the homeland of Japonic. Considering the spread of agriculture to Korea, I assume that the Japanese subsistence system based on the integration of rice and millet agriculture developed on the Korean Peninsula after rice had reached that area around $1500 \mathrm{BCE}$. The contact of rice and millet farmers shaped the Japonic language before it spread to the Japanese archipelago.

\section{Internal Migrations on the Japanese Archipelago}

I have dealt with the question of the homeland of Japonic as well as the route it may have taken before it entered the Japanese archipelago. In this section, I will focus on the speakers of Japonic after their arrival in Japan in the first millennium BCE until the first Old Japanese writings from the eighth century CE. I will do this by analysing old Japanese mythology and its implications for the spread of peoples across the Japanese archipelago. One important source for understanding the development of the early Japanese state is the Kojiki 古事記 (712 CE), the oldest extant Japanese chronicle. It seems that the compilers of the Kojiki were trying to incorporate local groups into the mythological stories to include them in the emperor's line and thus legitimise the emperor's rule over them (Wittkamp 2018: 58-59). Researchers generally agree that the Kojiki was designed as a political instrument by Emperor Tenmu 天皇 to secure rule over all the Wa lands.

According to Robert F. Wittkamp, the myths related to the ruling elite presumably came to Japan during the fifth century CE and are considered the northern line (system) hoppō-kei 北方系 of myths. In contrast to this, the southern line (system) nanpō$k e i$ 南方系 is much older and came to Japan in the Yayoi period (Wittkamp 2018: 5051).

For the development of the Japanese language, it is important to understand the carriers of the northern and southern line myths and their language associations. Evidence from the Sānguó zhì attests that the Japonic language was already present in the Japanese archipelago before the northern monarchical culture entered from the Korean Peninsula. Therefore, I will investigate whether the southern line myths can be connected to Yayoi people and thus likely to early speakers of Japonic.

\section{Japanese Mythology}

For assessing the question of whether carriers of the southern line myths spoke Japonic, it is necessary to understand how the southern line myths are represented in the mythological stories. One good example of how the northern and southern lines are interwoven in old Japanese mythology is the story of the brothers Howori 火遠理 and 
Hoderi 火照. Howori had a tool for hunting in the mountains and his elder brother Hoderi possessed a tool for hunting in the sea (a fishhook). ${ }^{18}$ One day, Howori suggested that they should exchange their tools, but even with the sea tool, Howori was unable to catch any fish and lost the fishhook in the sea. Thereupon, Hoderi wanted to get his fishhook back. Howori was sent to the Dragon Palace (Ryūgū-jō 竜宮城) and recovered the fishhook. Hoderi then vowed to serve Howori as his guard (Philippi 1969: 150-155). ${ }^{19}$

According to the system of Wittkamp, Howori can be related to the northern line of the ruling Yamato 大和 elite and Hoderi to the southern line myths. The Nihon shoki 日本書紀 (720 CE) gives Jinmu 神武, the first emperor of the Japanese Yamato state, the personal name of Hiko-hohodemi 彦火火出見, which is also another name for Howori in the Nihon shoki. Therefore, Howori may have been a duplicate of Jinmu or vice versa (Naumann 1996: 182). Nelly Naumann explains that it was politically necessary to integrate the myths of southern Kyūshū into the genealogy of the ruling house of the Yamato court (ibid). In the Kojiki version of the story, Hoderi is mentioned as the ancestor of the Hayato 隼人 people of southern Kyūshū (Philippi 1969: 147). Therefore, the capitulation of Hoderi, the ancestor of the Hayato people, to his younger brother Howori can be interpreted as showing the subjugation of the Hayato people of southern Kyūshū by Emperor Jinmu (Akima 1993: 158) and thus by the ancestors of the Yamato rulers. According to Edwina Palmer, the two brothers, Hoderi and Howori, and their association with the sea and the mountains respectively are reminiscent of Indonesian symbolism. On the Indonesian island of Bali, these two elements are contrasted - the mountains signify the home of the gods and the sea represents the habitat of the demons (Palmer 2010: 80). This poses the question of the role played by the myths of southern origin related to the Hayato people in the historical development of Japonic speakers on the Japanese islands.

\section{Hayato and the Earliest Speakers of Japonic}

The general continuity in genetic and archaeological materials suggests that the arrival of the Japonic language family also coincides with the initial Yayoi people. The Hayato long withstood the rising power from the Yamato regime until their final subjugation in the Kofun 古墳 period (300-710), but it is not known when they arrived in Japan. If the Hayato can be connected to Yayoi immigrants, this also implies that they may have spoken Japonic.

The most promising material for verifying the ancestry of the Hayato people is supplied by DNA data. Mitochondrial DNA of skeletons associated with the Hayato

\footnotetext{
${ }^{18}$ Philippi and Florenz translate the term written sachi 佐知 in the Kojiki as "luck" instead of "tool." Akima has "magic tools" (Akima 1993: 103).

${ }^{19}$ The story has been simplified for the sake of brevity.
} 
people has been analysed by Saiki Kazunobu 佐伯和信 and Wakebe Tetsuaki 分部 哲秋 (Saiki and Wakebe 2012: 105). Skeletons have been unearthed from six burial sites from the mountain area of south Kyūshū around Ebino えびの City, Miyazaki 宮崎 Prefecture (Saiki and Wakebe 2012: 106,112). After analysing thirty samples, Saiki and Wakebe concluded that the Hayato people share almost no characteristics with Jōmon populations and seem to be closer to people from the continent and thus Yayoi DNA (Saiki and Wakebe 2012: 122-123). This study indicates that the Hayato were early Yayoi immigrants. It remains to be seen if future research can confirm such a proposition.

Data on the Hayato language remains scarce; only two words remain in the $\bar{O}$ sumi fudoki 大隅国風土記 (Akimoto 1971: 526). Efforts to find connections to other languages thus remain speculative (Akita 1993). For this reason, assumptions on the Hayato language have been based on other factors such as geographical proximity, which led to a proposed connection to the Ryūkyūan languages of southern Japan. One such theory by Uemura Yukio 上村幸雄 states that the Ryūkyūan languages are a dialect of the Hayato language (Uemura 1977, cited in Serafim 2003: 463). This hypothesis was initially supported by Leon Serafim, but he later changed his view based on the relatively late date that was proposed for the southward move of the Ryūkyūan languages (Serafim 2003: 472-474). Further research on the Hayato people is needed to fully understand the role they played in the development of the Japonic language family.

\section{Hayato and Yamato Interactions}

Interactions between the Hayato and the Yamato court are described in the Kojiki and Nihon shoki. Before the Yamato court extended its power and subjugated the Hayato in the early fifth century CE, the Hayato were known as Kumaso 熊襲 (Ōbayashi 1975: 66), who first appear in the Nihon shoki (vol. 7) during the reign of Emperor Keikō 景行 (trad. r. 71-130 CE ${ }^{20}$ ).

The first mention of Hayato in service of the Yamato court can be found during the reign of Emperor Richū 履中 (trad. 400-405 CE; adjusted to 427-432 CE), so the subjugation of the Hayato by the Yamato probably happened between the fourth and fifth centuries. After being conquered, Hayato were employed in service to the Yamato court and reported to the emperor (Itō 2012). They were also known for their art performance and entertainment with singing and dancing (Hirama 2010: 75). ${ }^{21} \mathrm{I}$ thus assume that the Hayato were not a different ethnicity, but rather an opposing

\footnotetext{
${ }^{20}$ Archaeologists have proposed an adjusted chronology of reign dates based on excavations which corrects the reign dates of Keikō to 280-316 CE (cited in Barnes 2007: 24).

${ }^{21}$ Examples of this are contained in the Engishiki 延喜式 (vol. 7) and Shoku nihongi 続日本紀 (vol. $5)$.
} 
polity that spoke a similar language, and were eventually incorporated into the Yamato polity.

In my opinion, the Hayato came to southern Kyūshū from the Korean Peninsula during the early Yayoi period and spoke Japonic. Ultimately, research on the Hayato people may be able to provide better information to understand the early phases of the Yayoi period as well as the development of Japonic, thus advancing research on the origins of the Japanese languages.

\section{Conclusion}

In this article, I have dealt with the question of the origins of the Japanese languages and looked at available data from a variety of fields. While it is not possible to give a definite answer to this question, I will outline some preliminary results on how Japonic could have developed over time. My research suggests that Japonic corresponds with the Yayoi immigrants that came to Japan from the Korean Peninsula at the beginning of the first millennium BCE.

It is also congruent with the "farming/language dispersal hypothesis," which suggests that Japonic spread with the Yayoi immigrants and their wet rice agriculture. The Japanese subsistence system also indicates that speakers of Japonic were in contact with Koreanic speakers on the Korean Peninsula. Millet agriculture likely came from northern areas and mixed with wet rice agriculture of southern origin - either on the Korean Peninsula or in its vicinity. The fact that rice-related vocabulary is closely related to Austronesian in Japanese (unlike Koreanic), can be interpreted to mean that they are two different languages and that Japonic came from the south with a subsistence system based on rice. Additionally, it was also shown that the rice plants common in Japan stem from an area south of the Yangtze River. The route of language dispersal likely followed the spread of wet rice agriculture via the Korean Peninsula. This can also be seen in Japonic toponyms from the Korean Peninsula that demonstrate that Japonic was once spoken there.

After Japonic and wet rice agriculture were introduced to Japan, historical sources on Japanese mythology show a dual structure: a northern line that is usually associated with a monarchical culture of ancient Korean kingdoms came to Japan in the fourth or fifth century CE. The southern line myths are older and can be associated with the Hayato people of southern Kyūshū. Research on the DNA of the Hayato has shown that they were likely Yayoi people and therefore they may have been the earliest known speakers of Japonic that lived on the Japanese archipelago. 


\section{REFERENCES}

Akima, Toshio. 1993. "The Myth of the Goddess of the Undersea World and the Tale of Empress Jingū's Subjugation of Koguryŏ." Japanese Journal of Religious Studies, 20 (2-3), pp. 95185.

Akimoto, Kichirō 秋本吉郎. 1971 [1958]. Fudoki 風土記 [Fudoki]. Tōkyō 東京: Iwanami Shōten 岩波書店.

Akita, Yoshiaki 秋田義昭. 1993. “Hayato-zoku no kotoba no keifu 隼人族の言葉の系譜 [Genealogy of the Hayato Language].” Kashiigata 香椎潟 [Fukuoka Women’s University], 38, pp. 1-16.

Allan, Sarah. 1984. "The Myth of the Xia Dynasty." Journal of the Royal Asiatic Society of Great Britain and Ireland, 2, pp. 242-256.

Barnes, Gina L. 2007. State Formation in Japan: Emergence of a 4th-Century Ruling Elite. London: Routledge.

Beckwith, Christopher I. 2004. Koguryo, the Language of Japan's Continental Relatives: An Introduction to the Historical Comparative Study of the Japanese Koguryoic Languages with a Preliminary Description of Archaic Northeastern Middle Chinese. Leiden and Boston: Brill.

Beckwith, Christopher I. 2010. "Could There Be a Korean-Japanese Linguistic Relationship Theory? Science, the Data, and the Alternatives." International Journal of Asian Studies, 7 (2), pp. 201-219.

Bellwood, Peter. 2005. "Examining the Farming/Language Dispersal Hypothesis in the East Asian Context." In Laurent Sagart, Roger Blench, and Alicia Sanchez-Mazas, eds., The Peopling of East Asia. London and New York: Routledge Curzon, pp. 17-30.

Bellwood, Peter and Colin Renfrew, eds. 2002. Examining the Farming/Language Dispersal Hypothesis. Cambridge: McDonald Institute for Archaeological Research.

Benedict, Paul K. 1990. Japanese / Austro-Tai. Ann Arbor: Karoma Publ.

Bentley, John R. 2008. "The Search for the Language of Yamatai." Japanese Language and Literature, 42 (1), pp. 1-43.

Blust, Robert. 2013. The Austronesian Languages. Canberra: Asia-Pacific Linguistics.

Cheng, Hsiao-Chieh, Hui-Chen Pai Cheng, and Kenneth Lawrence Thern, trs. 1985. Shan Hai Ching: Legendary Geography and Wonders of Ancient China. Taipei: National Institute for Compilation.

Crowley, Terry and Claire Bowern. 2010. An Introduction to Historical Linguistics. Oxford: Oxford University Press.

Doerfer, Gerhard. 1974. "Ist das Japanische mit den altaischen Sprachen verwandt?" Zeitschrift der Deutschen Morgenländischen Gesellschaft, 124, pp. 103-142.

Elmer, Patrick. 2019. “Origins of the Japanese Languages: A Multidisciplinary Approach.” M.A. thesis. University of Vienna, Austria.

Forke, Alfred. 1907. Lun-Hêng. Part I: Philosophilcal Essays of Wang Ch'ung. Leipzig: Harrassowitz.

Forke, Alfred. 1962 [1911]. Lun-Hêng. Part II: Miscellaneous Essays of Wang Ch'ung. New York: Paragon Book Gallery.

Fujio, Shin'ichirō 藤尾慎一郎. 2014. “Nishinihon no Yayoi inasaku kaishi nendai 西日本の弥生 稲作開始年代 [When Did Wet Rice Cultivation with the Irrigation System Begin in Western Japan].” Kokuritsu Rekishi Minzoku Hakubutsukan Kenkyūhōkoku 国立歴史民俗博物館研究 報告 [Bulletin of the National Museum of Japanese History], 183, pp. 113-143.

Georg, Stefan, Peter A. Michalove, Alexis Manaster Ramer, and Paul J. Sidwell. 1999. “Telling General Linguists about Altaic.” Journal of Linguistics, 35 (1), pp. 65-98. 
Hanihara, Kazurō. 1991. "Dual Structure Model for the Population History of the Japanese." Japan Review, 2, pp. 1-33.

Hirama, Michiko 平間充子. 2010. "Hayato to Kuzu no geinō sōjō: ba no ronri kara sōgaku no yakuraku o yomu 隼人と国栖の芸能奏上: 場の論理から奏楽の脈絡を読む [Music and Dance Performances of Hayato and Kuzu: Reading the Context of Musical Performances through the Logic of Their Occasion]." Tōhōgakuendaigaku kenkyūkiyō 桐朋学園大学研究紀 要 [Tōhō Gakuen School of Music Faculty Bulletin], 36, pp. 75-88.

Hong, Wontack. 1994. Paekche of Korea and the Origin of Yamato Japan. Seoul: Kudara International.

Hudson, Mark J. 1999. Ruins of Identity: Ethnogenesis in the Japanese Islands. Honolulu: University of Hawai'i Press.

Hudson, Mark J. 2012. “'Austronesian' and 'Jōmon' Identities in the Neolithic of the Ryukyu Islands.” Documenta Praehistorica, 39 (1), pp. 257-262.

Iizuka, Masaru and Takahiro Nakahashi. 2002. "A Population Genetic Study on the Transition from Jomon People to Yayoi People.” Genes \& Genetic Systems, 77 (5), pp. 287-300.

Itabashi, Yoshizō 板橋義三. 1999. “Konsei gengo to nihongo no keisei katei 混成言語と日本語 の形成過程 [Mixed Languages and the Formation of Proto-Japanese]." Hikaku Shakai Bunka 比較社会文化 [Bulletin of the Graduate School of Social and Cultural Studies, Kyushu University], 5, pp. 41-55.

Itabashi, Yoshizō. 2003. "Austronesian-Altaic Language Mixing in Old Japanese: The Core Basic Vocabulary and Affixes.” Eurasian Studies Yearbook, 75, pp. 5-58.

Itabashi, Yoshizō 板橋義三. 2015. "Nihongo no genryū to keisei 日本語の源流と形成 [The Origins and Formation of the Japanese Language].” Nihon Seiri Jinrui Gakkaishi 日本生理人類 学会誌 [Japanese Journal of Physiological Anthropology], 20 (1), pp. 45-53.

Itō, Jun 伊藤循. 2012. “Enkishiki ni okeru Hayato no tennō shugo to 'Hayato = iteki-ron' hihan 延 喜式における隼人の天皇守護と「隼人=夷狄論」批判 [Protection of the Emperor by Hayato Under the Regulations of the Engishiki. Criticism of a Theory Regarding Hayato as Iteki Rank].” Jinbun Gakuhō 人文学報 [The Journal of Social Sciences and Humanities], 460, pp. 1-32.

Janhunen, Juha. 1992. "Das Japanische in Vergleichender Sicht.” Journal de La Société Finno-Ougrienne, 84 , pp. $145-161$.

Janhunen, Juha. 1994. “Additional Notes on Japanese and Altaic.” Journal de La Société FinnoOugrienne 85, pp. 236-240, pp. 256-260.

Janhunen, Juha. 2005. “The Lost Languages of Koguryŏ.” Journal of Inner and East Asian Studies, 2 (2), pp. 66-86.

Kawamoto, Takao 川本崇雄. 1977. “Toward a Comparative Japanese-Austronesian I.” Bulletin Nara University Education, 26 (1), pp. 23-49.

Kidder, J. Edward. 2007. Himiko and Japan's Elusive Chiefdom of Yamatai: Archaeology, History, and Mythology. Honolulu: University of Hawai'i Press.

Lee, Gyoung-Ah. 2011. "The Transition from Foraging to Farming in Prehistoric Korea." Current Anthropology, 52 (4), pp. 307-329.

Lee, Sean and Toshikazu Hasegawa. 2011. "Bayesian Phylogenetic Analysis Supports an Agricultural Origin of Japonic Languages.” Proceedings of the Royal Society, 278 (1725), pp. 3662-3669.

Lu, Tracey. 1998. "The Transition from Foraging to Farming and the Origin of Agriculture in China." Ph.D. thesis. Australian National University, Australia.

Lu, Tracey. 2012. "Periphery or Land of Cultural Dynamics: Rethinking Prehistoric South China." Documenta Praehistorica, 39, pp. 111-135. 
Martin, Samuel Elmo. 1966. “Lexical Evidence Relating Korean to Japanese.” Language: Journal of the Linguistic Society of America, 42 (2), pp. 185-251.

Miller, Roy Andrew. 1971. Japanese and the Other Altaic Languages. Chicago: University of Chicago Press.

Miyake, Marc Hideo. 2003. "Philological Evidence for *e and *o in Pre-Old Japanese." Diachronica, 20 (1), pp. 83-137.

Miyamori, Daisuke, Noboru Ishikawa, Nozomi Idota, Yasuhiro Kakiuchi, Stuart McLean, Tadaichi Kitamura, and Hiroshi Ikegaya. 2015. "Tracing Jomon and Yayoi Ancestries in Japan Using ALDH2 and JC Virus Genotype Distributions.” Investigative Genetics, 6 (14), pp. 1-5.

Miyamoto, Kazuo. 2016. "Archaeological Explanation for the Diffusion Theory of the Japonic and Koreanic Language.” Japanese Journal of Archaeology, 4 (1), pp. 53-75.

Murayama, Shichirō 村山七郎 and Taryō Ōbayashi 大林太良. 1973. Nihongo no kigen 日本語の 起源 [The Origins of Japanese]. Tōkyō 東京: Kōbundō 弘文堂.

Nam, Pung-hyun. 2012. “Old Korean.” In Nicolas Tranter, ed., The Languages of Japan and Korea. London: Routledge, pp. 41-72.

Nasu, Hiroo and Arata Momohara. 2016. "The Beginnings of Rice and Millet Agriculture in Prehistoric Japan.” Quaternary International, 397, pp. 504-512.

Naumann, Nelly. 1996. Die Mythen des alten Japan. München: Beck.

Nienhauser, William H., ed. 2006. The Grand Scribe's Records. Volume V.1: The Hereditary Houses of Pre-Han China, Part 1. Bloomington: Indiana University Press.

Ōbayashi, Taryō 大林太良. 1975. Hayato隼人 [Hayato]. Tōkyō東京: Shakai Shisōsha 社会思想 社.

Ōno, Susumu 大野晋. 1970 [1957]. The Origin of the Japanese Language. Tokyo: Kokusai Bunka Shinkokai.

Palmer, Edwina. 2010. "Out of Sundaland: The Provenance of Selected Japanese Myths.” In James C. Baxter, ed., Localization, and Japanese Studies in the Asia-Pacific Region. Kyoto: Kokusai Nihon Bunka Kenkyū Sentā, pp. 67-88.

Pellard, Thomas. 2005. “Koguryo, the Language of Japan's Continental Relatives: An Introduction to the Historical-Comparative Study of the Japanese-Koguryoic Languages with a Preliminary Description of Archaic Northeastern Middle Chinese (Review).” Korean Studies, 29, pp. 167170.

Pellard, Thomas. 2015. "The Linguistic Archeology of the Ryukyu Islands.” In Heinrich Patrick, Shinsho Miyara, and Michinori Shimoji, eds., Handbook of the Ryukyuan Languages: History, Structure, and Use. Berlin: De Mouton Gruyter, pp. 13-37.

Philippi, Donald L. 1969. Kojiki. Princeton: Princeton University Press.

Rhee, Song-Nai, C. Melvin Aikens, Sung-Rak Choi, and Hyuk-Jin Ro. 2007. "Korean Contributions to Agriculture, Technology, and State Formation in Japan: Archaeology and History of an Epochal Thousand Years, 400 B.C.-A.D. 600." Asian Perspectives, 46 (2), pp. 404-459.

Robbeets, Martine. 2005. Is Japanese Related to Korean, Tungusic, Mongolic and Turkic? Wiesbaden: Harrassowitz.

Robbeets, Martine. 2017. “Austronesian Influence and Transeurasian Ancestry in Japanese.” Language Dynamics and Change 7 (2), pp. 210-251.

Saiki, Kazunobu 佐伯和信 and Tetsuaki Wakebe 分部哲秋. 2012. "Minami Kyūshū Kofunjin o mitokondoria DNA kaiseki no genjō 南九州古墳人のミトコンドリアDNA解析の現状 [Status Quo of the Analysis of Mitochondrial DNA of the Kofun People of Southern Kyūshū].” In Takigawa Wataru 瀧川涉, ed., Kotsu Kōkogaku to Emishi/Hayato 骨考古学と 蝦夷・隼人 [Osteological Archaeology and Emishi/Hayato]. Tōkyō 東京: Dōseisha 同成社, pp. 105-125. 
Sakiyama, Osamu 崎山理. 2012. "Nihongo no kongō-teki tokuchō: Ōsutoroneshia sogo kara kodai nihongo e oto hōsoku to imi henka 日本語の混合的特徵: オーストロネシア祖語から古代 日本語へ音法則と意味变化 [Japanese as a Mixed Language: Sound Law and Semantic Change from Proto Austronesian to Ancient Japanese].” Kokuritsu minzokugaku hakubutsukan $k e n k y \bar{u} h \bar{o} k o k u$ 国立民族学博物館研究報告 [Bulletin of the National Museum of Ethnology], 36 (3), pp. 353-393.

Satō, Yōichirō 佐藤洋一郎. 1992. "Nihon no ine no denpa keiro 日本のイネの伝播経路 [The Routes of Introduction of Rice in Japan].” Nihon jōzo kyōkai 日本醸造協会 [Journal of the Brewing Society of Japan], 87 (10), pp. 732-738.

Schuessler, Axel. 2009. Minimal Old Chinese and Later Han Chinese. Honolulu: University of Hawai'i Press.

Serafim, Leon. 2003. "When and from Where Did the Japonic Language Enter the Ryukyus? A Critical Comparison of Language, Archaeology, and History." In Alexander Vovin and Toshiki Osada, eds., Perspectives on the Origins of the Japanese Language. Nichibunken Japanese Studies Series 31. Kyoto: International Research Center for Japanese Studies, pp. 463476.

Shitara, Hiromi 設楽博己. 2014. “Nōkō bunka fukugō to Yayoi bunka 農耕文化複合と弥生文化 [Yayoi Culture as a Complex of Multiple Farming Cultures].” Kokuritsu rekishi minzoku hakubutsukan kenkyūhōkoku 国立歴史民俗博物館研究報告 [Bulletin of the National Museum of Japanese History], 185, pp. 449-469.

Shōda, Shin'ya. 2007. "A Comment on the Yayoi Period Dating Controversy." Bulletin of the Society for East Asian Archaeology, 1, pp. 1-7.

Solnit, David B. 1992. “Japanese /Austro-Tai, by Paul K. Benedict (review).” Language, 68 (1), pp. 188-196.

Song, Ho Jung. 2004. "The Formation of Gojoseon and Its Social Characteristics." The Review of Korean Studies, 7 (1), pp. 95-113.

Starostin, Sergei. 1991. Altajskaja Problema i Proisxoždenie Japonskogo Jazyka [The Altaic Problem and the Origin of the Japanese Language]. Moscow: Nauka.

Starostin, Sergei, Anna Dybo, and Oleg Mudrak. 2003. Etymological Dictionary of the Altaic Languages. Leiden and Boston: Brill.

Stevens, Chris J. and Dorian Q. Fuller. 2017. "The Spread of Agriculture in Eastern Asia: Archaeological Bases for Hypothetical Farmer/Language Dispersals.” Language Dynamics and Change; 7 (2), pp. 152-186.

Strassberg, Richard E. 2002. A Chinese Bestiary: Strange Creatures from the Guideways Through Mountains and Seas. Berkeley: University of California Press.

Summerhayes, Glenn R. and Atholl Anderson. 2009. "An Austronesian Presence in Southern Japan. Early Occupation in the Yaeyama Islands." Ippa Bulletin; 29, pp. 76-91.

Takahashi, Ryūzaburō. 2009. "Jomon, Yayoi, and Ainu in Japan: Symbiotic Relations between Paddy-Field Rice Cultivators and Hunter-Gatherer-Fishers in Japanese Prehistory: Archaeological Considerations of the Transition from the Jomon Age to the Yayoi Age." Senri Ethnological Studies, 73, pp. 71-97.

Takamiya, Hiroto. 2001. "Introductory Routes of Rice to Japan: An Examination of the Southern Route Hypothesis." Asian Perspectives, 40 (2), pp. 209-226.

Trairong, Suwankiri and Ben-li Wu. 2016. The Unbroken Chain: State Wu in Ancient China and in Siam (Thailand). Hongkong: China Intl Culture Press.

Unger, James Marshall. 1990. "Summary Report of the Altaic Panel." In Philip Baldi, ed., Linguistic Change and Reconstruction Methodology. Part 1. Berlin: De Gruyter, pp. 479-482. 
Unger, James Marshall. 2001. "Layers of Words and Volcanic Ash in Japan and Korea.” Journal of Japanese Studies, 27 (1), pp. 81-111.

Unger, James Marshall. 2009. The Role of Contact in the Origins of the Japanese and Korean Languages. Honolulu: University of Hawai 'i Press.

Vovin, Alexander. 1999. “Altaic, So Far.” Migracijske Teme, 15 (1-2), pp. 155-213.

Vovin, Alexander. 2009. "Japanese, Korean, and Other 'Non-Altaic' Languages." Central Asiatic Journal, 53 (1), pp. 105-147.

Vovin, Alexander. 2010. Koreo-Japonica: A Re-Evaluation of a Common Genetic Origin. Honolulu: University of Hawai'i Press.

Vovin, Alexander. 2013. "From Koguryǒ to T'amna: Slowly Riding to the South with Speakers of Proto-Korean." Korean Linguistics, 15 (2), pp. 222-240.

Whitman, John. 1985. "The Phonological Basis for the Comparison of Japanese and Korean." Ph.D. thesis, Harvard University, United States of America.

Whitman, John. 2010. "The Role of Contact in the Origins of the Japanese and Korean Languages (review)." The Journal of Asian Studies, 69 (4), pp. 1268-1270.

Whitman, John. 2011. "Northeast Asian Linguistic Ecology and the Advent of Rice Agriculture in Korea and Japan." Rice, 4 (3-4), pp. 149-158.

Whitman, John and Mark J. Hudson. 2017. "Millets, Rice, and Farming/Language Dispersals in East Asia." Language Dynamics and Change, 7 (2), pp. 147-151.

Wittkamp, Robert F. 2018. "The Body as a Mode of Conceptualization in the Kojiki Cosmogony." Bulletin of the Institute of Oriental and Occidental Studies, Kansai University, 51, pp. 47-64.

Yasuda, Yoshinori 安田喜憲. 2009. Inasaku gyorō bunmei: Chōkō bunmei kara Yayoi bunka e 稲 作漁撈文明一長江文明から弥生文化へ [Rice Cultivation and Fishing Culture: From the Yangtze Civilisation to Yayoi Culture]. Tōkyō 東京: Yuzankaku 雄山閣.

Zgusta, Richard. 2015. The Peoples of Northeast Asia through Time: Precolonial Ethnic and Cultural Processes along the Coast between Hokkaido and the Bering Strait. Leiden and Boston: Brill.

\section{GLOSSARY}

Amami

Ariake-kai

Chángjiāng

Chén Shòu

Chéng

Chosŏn

Ch'ungch'ŏngbuk

Ebino

Engishiki
奄美

有明海

長江

陳壽

成

朝鮮
Island group in northern Ryūkyū

Ariake Sea to the west of

Kyūshū

Yangtze River in China

Chinese scribe and historian (233-297)

king of the Zhōu dynasty (trad. r. 1042-1021 BCE)

ancient kingdom on the Korean Peninsula (until 108 BCE) now referred to as Kojosŏn. Not to be confused with the later Chosŏn dynasty (1392-1910)

North Ch'ungch'ŏng Province in South Korea city in Miyazaki Prefecture Japanese book about laws and customs completed in 927 
Fujio Shin'ichirō

Fukuoka

Gài chiefdom

Genkai-nada

Gishi-Wajinden

Kojosŏn

Hachijō
Hàn
Hanihara Kazurō
Hayato
Hiko-hohodemi

Hoderi

\section{Hoppō-kei}

Howori

Iki-no-shima

Itabashi Yoshizō

Itazuke

Jiāngsū

Jìì̀

Jìn

Jīng Mán

Jinmu

Jinshū

Jōmon

Kaema

Kansai

Kawamoto Takao

Keikō

Kofun
藤尾慎一郎

福岡

蓋國

玄界灘

魏志倭人伝

古朝鮮

八丈

漢

埴原和郎

隼人

彦火火出見

火照

北方系

火遠理

声岐島

板橋義三

板付

江蘇

季歷

育

荊蠻

神武

晉書

縄文

蓋馬

関西

川本崇雄

景行

古墳
Japanese author

place in the north of Kyūshū

polity north of Wa mentioned in

the Shānhăijīng

Genkai Sea to the north of the island Kyūshū

section on the Wa people in the Sānguó zhì

name for the ancient kingdom

Chosŏn often applied in contemporary sources

island group south of Tōkyō

Chinese dynasty (202 BCE-220

CE)

Japanese author

ethnic group of southern Kyūshū

personal name of Emperor

Jinmu in the Nihon shoki

Japanese deity and older brother of Howori

Northern line myths in Japanese mythology

Japanese deity and younger brother of Hoderi

Iki Island between Korea and Japan

Japanese author

excavation site in Fukuoka

province in eastern China

youngest son and heir of King

Tài of Zhōu

Chinese dynasty (265-418)

historical group of people in

southeastern China

legendary emperor of Japan

(trad. r. 660-585 BCE)

history of the Jin dynasty written in the seventh century CE period in the history of Japan

(ca. 15,000-300 BCE [disputed])

highland in North Korea

region in central Japan

Japanese author

twelfth emperor of Japan (trad.

r. 71-130)

period in the history of Japan

(300-710) 


\begin{tabular}{|c|c|c|}
\hline Koguryŏ & 高句麗 & $\begin{array}{l}\text { one of the three Korean king- } \\
\text { doms (trad. } 37 \mathrm{BCE}-668 \mathrm{CE} \text { ). }\end{array}$ \\
\hline Kojiki & 古事記 & $\begin{array}{l}\text { first extant Japanese chronicle } \\
\text { completed in } 712\end{array}$ \\
\hline Kuàijī & 會稽 & mountain in southeastern China \\
\hline Kumaso & 熊襲 & ethnic group of southern Kyūshū \\
\hline Kyūshū & 九州 & $\begin{array}{l}\text { one of the four main islands of } \\
\text { Japan }\end{array}$ \\
\hline Liáng shū & 梁書 & $\begin{array}{l}\text { Book of Liáng written in the sev- } \\
\text { enth century }\end{array}$ \\
\hline Liáodōng & 遼東 & $\begin{array}{l}\text { peninsula in China close to the } \\
\text { border with North Korea }\end{array}$ \\
\hline Liáoníng & 辽宁 & $\begin{array}{l}\text { province in China close to the } \\
\text { border with North Korea }\end{array}$ \\
\hline Lùnhéng & 論衡 & $\begin{array}{l}\text { Chinese classical text from } 80 \\
\text { CE }\end{array}$ \\
\hline Miyako & 宮古 & $\begin{array}{l}\text { island group in southern Ryūkyū } \\
\text { between Okinawa and Yaeyama }\end{array}$ \\
\hline Miyamoto Kazuo & 宮本一夫 & Japanese author \\
\hline Miyazaki & 宮崎 & $\begin{array}{l}\text { Miyazaki Prefecture in the south } \\
\text { of Kyūshū }\end{array}$ \\
\hline Mumun & 無文 & $\begin{array}{l}\text { period in the history of Korea } \\
\text { (ca. 1500-300 BCE) }\end{array}$ \\
\hline Murayama Shichirō & 村山七郎 & Japanese author \\
\hline Nanpō-kei & 南方系 & $\begin{array}{l}\text { Southern line myths in Japanese } \\
\text { mythology }\end{array}$ \\
\hline Nihon shoki & 日本書紀 & $\begin{array}{l}\text { second extant Japanese chroni- } \\
\text { cle completed in } 720\end{array}$ \\
\hline Níngzhèn & 宁镇 & area in Jiāngsū Province \\
\hline Ōbayashi Taryō & 大林太良 & Japanese author \\
\hline Okinawa & 沖縄 & island group in central Ryūkyū \\
\hline Ōno Susumu & 大野晋 & Japanese author \\
\hline $\bar{O}$ sumi fudoki & 大隅国風土記 & gazetteer of Ōsumi Province \\
\hline Paekche & 百濟 & $\begin{array}{l}\text { one of the three Korean king- } \\
\text { doms (trad. } 18 \text { BCE-660 CE). }\end{array}$ \\
\hline Richū & 履中 & $\begin{array}{l}\text { seventeenth Emperor of Japan } \\
\text { (trad. r. } 400-405 \text { ) }\end{array}$ \\
\hline Ryūgū-jō & 竜宮城 & $\begin{array}{l}\text { Dragon Palace at the bottom of } \\
\text { the sea in Japanese mythology }\end{array}$ \\
\hline Ryūkyū & 琉球 & $\begin{array}{l}\text { island chain south of the Japa- } \\
\text { nese mainland }\end{array}$ \\
\hline Sachi & 佐知 & magic tool, luck \\
\hline Saiki Kazunobu & 佐伯和信 & Japanese author \\
\hline Sakiyama Osamu & 崎山理 & Japanese author \\
\hline Samguk sagi & 三國史記 & $\begin{array}{l}\text { oldest extant Korean chronicle } \\
\text { completed in } 1145\end{array}$ \\
\hline Sānguó zhì & 三國志 & $\begin{array}{l}\text { History of the Three Kingdoms } \\
\text { compiled in the third century } \mathrm{CE}\end{array}$ \\
\hline Satō Yōichirō & 佐藤洋一郎 & Japanese author \\
\hline
\end{tabular}




\begin{tabular}{|c|c|}
\hline Seoul [Sŏul] & 서울 \\
\hline Shāndōng & 山東 \\
\hline Shānhăijīng & 山海經 \\
\hline Shăo Kāng & 少康 \\
\hline Shijì & 史記 \\
\hline Shinmura Izuru & 新村出 \\
\hline Shitara Hiromi & 設楽博己 \\
\hline Shoku nihongi & 続日本紀 \\
\hline Silla & 新羅 \\
\hline Tài of Zhōu & 周太 \\
\hline Tàibó & 太伯 \\
\hline Tàizōng & 太宗 \\
\hline Táng & 唐 \\
\hline Tenmu & 天皇 \\
\hline Uemura Yukio & 上村幸雄 \\
\hline Wajin & 倭人 \\
\hline Wakebe Tetsuaki & 分部哲秋 \\
\hline Wú & 吳 \\
\hline Wúyuè chūnqiū & 吴越春秋 \\
\hline Xià & 夏 \\
\hline Yaeyama & 八重山 \\
\hline Yamato & 大和 \\
\hline Yàn & 燕 \\
\hline Yasuda Yoshinori & 安田喜憲 \\
\hline Yayoi & 弥生 \\
\hline Yonaguni & 与那国 \\
\hline Yuè & 越 \\
\hline Zhòngyōng & 仲雍 \\
\hline Zhōu & 周 \\
\hline
\end{tabular}

capital of South Korea

peninsula in eastern China facing the Korean Peninsula

Guideways through Mountains and Seas

king of the Xià dynasty

Records of the Grand Historian finished around $94 \mathrm{BCE}$ Japanese author

Japanese author

Japanese historical text completed in 797

one of the three Korean kingdoms (trad. 57 BCE-935 CE). leader of the Zhōu clan in old Chinese sources and father of Tàibó, Zhòngyōng, and Jilì founder of the Wú state in old Chinese sources second emperor (r. 626-649) of the Táng dynasty Chinese dynasty (618-907) fortieth emperor of Japan (r. 673-686)

Japanese author term referring to Japanese people in old Chinese sources Japanese author

Chinese State (ca. eleventh century-fifth century BCE) The Annals of State Wú and State Yuè ancient Chinese dynasty (trad. ca. 2200-1760 BCE) island group in southern Ryūkyū Yamato court centred in the Kansai region

Yàn State (ca. eleventh centurythird century BCE)

Japanese author period in the history of Japan (ca. 300 BCE (disputed)-300 CE)

Southern Ryūkyū island and part of the Yaeyama islands ancient state in southern China second ruler of the Wú state in old Chinese sources Chinese dynasty (ca. eleventh century-third century BCE) 
*mat-lia

$*^{*} ə^{\mathrm{B}}$-liai

*pie-ko ${ }^{\mathrm{B}}$

*tuəs-ma ${ }^{\mathrm{B}}$

*?it-kie

*?i-to
末盧

母離

卑狗

對馬

一支

伊都
Matsura in northern Kyūshū Old Japanese mori "guard"

Old Japanese piko "prince"

Tsushima in northern Kyūshū

Iki in northern Kyūshū

Itoshima in northern Kyūshū 